\title{
Entrepreneurship Education: Comparative Study of Initiatives of two Partner Universities
}

\author{
By Stefan Op 't Hoog ${ }^{*}$, Dimitra Skoumpopoulou ${ }^{\dagger}$
}

The education of entrepreneurship is considered the most effective method to stimulate entrepreneurship within a society (Aaltio \& Eskelinen, 2016); hence, creating jobs and encouraging economic growth (Lackéus, 2015). There are nevertheless structural difficulties in teaching entrepreneurship (Yang, 2016), and institutions are often left with the question: 'learning-by-doing-what?' This is particularly worrisome for partner universities who are supposed to collaborate to benefit the student. This study examines which initiatives two partner universities have integrated regarding the concept of entrepreneurship education, and to what extent these initiatives are in accordance with the already established literature. The analysis of the results from the qualitative data gathered through interviews shows that both universities lack certain important aspects of entrepreneurship education in their current offerings. It was found that University A seems to lack cohesion between the different faculties, has not integrated a global approach, has weak links with SMEs and social impact companies, and offers experiential-based learning mainly with in-class activities. University B, on the other hand, shows an improper use of terminology regarding the concept of entrepreneurship, lacks the collaboration with large corporations and social impact companies, and has a short-term approach for its programs as opposed to the more effective long-term approach. In addition, both universities fail to widely integrate entrepreneurship across the university. The research shows that there is no generally accepted understanding of how universities should structure their entrepreneurial environment. This study aims at discovering and contrasting the current initiatives to stimulate entrepreneurship at university level by comparing two partner universities in the United Kingdom and The Netherlands.

Keywords: entrepreneurial education, institutions, qualitative technique.

\section{Introduction}

Entrepreneurship education is recognised as the single most important method of fostering entrepreneurship, and thus job creation and economic growth (Aaltio \& Eskelinen, 2016). The integration of entrepreneurship into education has gained significance over the last few decades. Governments and educational institutions have acknowledged that adopting the concept is likely to result in economic growth and job creation for the former, and growing school involvement and reduced inequality for the latter (Lackéus, 2015; Urban \& Kujinga, 2017). Innovation and entrepreneurship are described as the key drivers in the global economy, opening new markets with the introduction of

\footnotetext{
*Associate Head of the Marketing, Operations and Systems Departement, Northumbria University, UK.

${ }^{\dagger}$ Senior Lecturer, Northumbria University, UK.
} 
new products and technological advancements (Karlsson, Grasjo, \& Wixe, 2015).

With its first introduction in the United States in the 1940s, entrepreneur-ship education has been widely accepted as a new drive for economic growth and innovation (Zhou \& Xu, 2012). The concept has gained popularity ever since, and was in 1998 adapted by UNESCO (1998, p. 2) at the World Conference on Higher Education, arguing, "developing entrepreneurial skills and initiatives should become major concerns of higher education". Ever since, the number of entrepreneurship courses, students and academics have skyrocketed and the trend shows no sign of abating. Miri $(2014$, p.1) calls it "the revolution of the twenty-first century", where governments encourage the next generation to adapt an entrepreneurial mind-set to prosper in the rapidly changing world.

After research and teaching, entrepreneurship forms the core of the upcoming 'third mission' at universities, described by Mitra and Edmondson (2015, p. 285) as, "the delivery of community and economic development activities that generate social and economic benefits". Recognised as an essential part of higher education, entrepreneurship programs are evolving quickly and an increasing number of universities are incorporating courses on business planning, innovation and creativity, and new venture development. Besides the development of key entrepreneurial skills, universities have set up a range of initiatives for start-up support, generally ranging from basic physical facilities, such as mentors and grants, to a more advanced support infrastructure with business incubators and technology transfer offices (Mitra \& Edmondson, 2015; OECD, 2009).

At the same time, there are structural difficulties in teaching entrepreneur-ship (Yang, 2016). The message that can be drawn is that there is no generally accepted understanding of how universities should structure their entrepreneurial environment. With no clear guidelines on how to effectively stimulate entrepreneurship, universities are often granted the freedom to structure their own entrepreneurial environment, directly influencing start-up success (Information Resources Management Association, 2017). When relating this to two partner universities in the United Kingdom and The Netherlands, it could be mutual beneficial to streamline which entrepreneurial support initiatives have been implemented, and what can be improved upon. In fact, both countries are listed in the top-15 of the 2016 Global Entrepreneurship Index, indicating a similar favourable entrepreneurial climate (Acs, Szerb, \& Autio, 2017). This paper aims at discovering and contrasting the current initiatives to stimulate entrepreneurship at university level by comparing two partner universities in the United Kingdom and The Netherlands.

The scope of this paper is narrowed down to solely entrepreneurship initiatives at UK-based University A and Netherlands-based University B. Despite the numerous other variables that affect the entrepreneurial environment, such as subsidies and other resources from the public education sector, this research is limited to the universities' initiatives on promoting entrepreneurship.

The authors have identified the following research objectives:

1. To identify the purpose of entrepreneurship education and to what extent it is considered important by academics. 
2. To investigate the approach to entrepreneurship education in order to benefit students.

3. To analyse and contrast the entrepreneurial initiatives implemented at case study universities and to what extent it can be enhanced.

\section{Literature Review}

\section{The Rise of Entrepreneurship Education}

French economist Jean-Baptiste Say first defined entrepreneurship in the 1800s as, "the entrepreneur shifts economic resources out of an area of lower and into an area of higher productivity and greater yield". Over the years, the entrepreneur has become immensely important and is perceived as the engine of global economic development by driving industrialisation, generating employment and decreasing income inequality (Lackéus, 2015).

Despite the acknowledged impact of entrepreneurship on social and economic well-being, for a long time the general feeling was that entrepreneurs were born, not made (Moroz and Hindle, 2012). Jones, Macpherson, and Jayawarna (2013) support this view, suggesting that entrepreneurs are born with certain characteristics, but that the intensification of certain skills through learning will help them become successful.

Raposo and Paço (2011) argue that entrepreneurship education is focused on stimulating entrepreneurship in terms of start-ups, whereas enterprise education is about developing enterprising people with an attitude of self-reliance. Kompf (2012) and Shockley (2009) further suggest that entrepreneur-ship and enterprise education should be separated, with the former being taught to individuals seeking to create a business, and the latter being delivered across the university.

From an economic and society perspective, the growing popularity in entrepreneurship education is mainly due to the potential for stimulating innovation and economic growth, and reducing unemployment (Kuratko and Hoskinson, 2017). Hence, the interest for embedding entrepreneurship education in engineering and social studies is growing significantly to develop an entrepreneurial mind-set among all levels of education (Aaltio and Eskelinen, 2016). Yet, Europe is found to lag behind the United States and Canada in entrepreneurial activity, and is therefore pressured to integrate entrepreneurship across all institutions to support the expansion of entrepre-neurship education at university level (Riviezzo, Nisco, \& Napolitano, 2012).

Also, the demand for entrepreneurship courses is growing explosively. Academia is aspired to have a positive impact on economic development while Valerio, Parton, and Robb (2014), suggest that the interest in entrepreneurship is due to scholars' personality traits as high risk-takers and control-seekers. In response, universities are motivated to support entrepreneurial courses to not only improve their competitive advantage, but also to strengthen their alumni networks and enjoy widely acknowledged status and reputation (Fetters, Greene, \& Rice, 
2010; Sá \& Kretz, 2015). This indicates that institutions act generally with their own interests' at heart.

The authors believe that the scope of entrepreneurship should not be limited, in order to prevent narrow-minded entrepreneurial approaches. This is considered true, as an international approach on entrepreneurship education is believed to further enhance students' skills to the extent that they understand different ways of doing business (Rae \& Woodier-Harris, 2013). Not only is this necessary globally, but also within organizations. Since not all students will set up their own company, they can still utilize their entrepreneurial skills in different types of organizations.

\section{Entrepreneurship Education at University level}

Entrepreneurship programs have been implemented at different levels of the educational system, from primary school to university (Rahman, 2016). The exposure to entrepreneurship at an early age is more likely to result in entrepreneurial activity in a later stage in life (Rae \& Wang, 2015). As written by Hosu and Iancu (2016), the role of higher education institutions is the most critical, as universities are influencing scholars to form start-ups and thus directly contributing to the economic development of a country. Especially, the influence of the institution's decision-makers is significant, as they contribute to student learning by means of strategy, mentoring and networking activities (Welsh, 2014). This focus is especially evident in the growing number of entrepreneurship centres at universities, providing a range of services and programs that stimulate entrepreneurial activity and economic development (Kuratko \& Hoskinson, 2017).

The impact of entrepreneurship education is nevertheless dependent on a country's cultural context, with an explicit role for religion and values, people's attitude, family and community influence, and government policies and politics (Ehiobuche \& Madueke, 2017; Telman, 2012). The focus of this paper is on two partner universities in the United Kingdom and The Netherlands, thus we consider any literature related to entrepreneurship education at universities in those countries.

\section{Entrepreneurship Education at UK Universities}

Ever since the year 2000, when business and entrepreneurial development was listed as a strategic focus for UK Universities, the concept of entrepreneurship education has been recognised as a priority in universities. The government has however not implemented a national strategy to support entrepreneurship education, but has instead adopted multiple initiatives related to entrepreneurship education (Lackéus, 2015). In fact, entrepreneurship programmes are mostly regulated on a regional or institutional level (EACEA, 2012). As a result, there is a wide diversity of initiatives to support entrepreneurship education at UK universities, ranging from guidance materials for teachers and entrepreneurship competitions for scholars, to online resources and web portals for case studies (Pantea, Diroescu, \& Podlasek-Ziegler, 2014). The one characteristic that unites 
UK universities is the fact that they have the institution's best interests at heart, as opposed to the interests of teachers or students (Wright, 2007).

The UK is building on its reputation as one of the 'most entrepreneurial' countries in Europe (Myers, 2014). According to the Global Entrepreneurship Development Institute, only Switzerland, Sweden, Denmark and Iceland ranked higher in 2017. In comparison, in 2012 and 2013 the United Kingdom ranked $14^{\text {th }}$ and ninth, respectively. This favourable environment for start-ups is generally created within universities and its nationwide expansion in the United Kingdom is due to benefits ranging from improved student employability skills, to their input to prevent economic stagnation or decline both in the United Kingdom and worldwide (Papadopoulos, Burger, \& Faria, 2016). The acknowledged impact that entrepreneurial students have on the economy has triggered universities to further expand their entrepreneurial program as well as extracurricular entrepreneur support activities (Nicolescu \& Lloyd-Reason, 2016). Nevertheless, the entrepreneurial initiatives tend to be too theoretical, as opposed to practical implementation of ideas and solutions.

\section{Entrepreneurship Education at Dutch Universities}

In the last couple of years, the number of education institutions in The Netherlands that offer entrepreneurship programs in their educational environment has increased significantly (Bijaoui, 2015). Since 2000, the Dutch government has been stimulating educational programs on entrepreneurship (EACEA, 2012). Subsidy-related initiatives included the 2007 Education and Entrepreneurship Action Program and the 2009 Education Networks Enterprise, which aimed at increasing the number of institutions offerings entrepreneurial programs and encouraging scholars with an entrepreneurial mind-set to participate in these courses. Moreover, several programs were set out by the Dutch government in an effort to increase the number of scholars launching their own firm within five years from graduation (EACEA, 2012).

According to the Netherlands Enterprise Agency, the government is promoting this initiative for educational institutions to integrate an entrepreneurial culture by offering subsidies, without exerting control over the program design. However, the result of the high degree of autonomy is that entrepreneurship education is not structurally and consistently integrated in institution programs, but is rather demand-driven (EACEA, 2012). Despite the autonomous decision-making, the growing interest in entrepreneurship education has not stagnated, as universities are subsidised to setup programs together with local firms to put theoretical knowledge into practice.

Where the United Kingdom has adopted a strategy of integrating multiple initiatives related to entrepreneurship education, the Dutch government has chosen for an action plan focused specifically on the integration on entrepreneurship programs (EACEA, 2012). However, both countries do not have a national strategy linked to entrepreneurship education, as opposed to Scandinavia and countries in the western Balkans (EACEA, 2016). The OECD (2009), nevertheless, created objectives for its member countries, including the United 
Kingdom and The Netherlands, to integrate entrepreneurship across institutions and partner with external business support centres and networks. This indicates that universities in both countries are encouraged to stimulate entrepreneurial initiatives, but still lack transparency and guidance in how to enhance current entrepreneurial offerings.

\section{The Impact of Entrepreneurship Education}

While the overall goal of entrepreneurship education programs is to teach the desirability as well as the practicality of entrepreneurship (Passiante \& Romano, 2016), the extent to which it impacts one may be influenced by several variables such as culture, role models, individual characteristics and the educational environment (Hytti et al., 2016).

As stated before, entrepreneurship is widely recognised as a driver for economic growth and employment. Moreover, it is argued that the rise of entrepreneurship education is due to the globalised, uncertain and complex environment we live in, demanding entrepreneurial engagement from people and companies in order to survive (Fayolle \& Redford, 2014). In addition to the influence entrepreneurship has on the economy, the effects are also evident on students' and workers' relevancy, involvement and encouragement in both education and at work (Baptista \& Leitão, 2015). Besides the economic benefits, the authors recognize a trend in entrepreneurship to encounter societal challenges. Ahmetoglu (2017) identified that entrepreneurship education is shifting to encounter societal challenges by focusing on value creation for the public good.

The promotion of the entrepreneurial mind-set contributes nevertheless to a broader scope in society. The positive impact of entrepreneurial programs on students' interest, joy, engagement and creativity is significant (Morris \& Liguori, 2016). This, in turn, has increased students' motivation and decreased student boredom and dropout rates (Reffstrup \& Christiansen, 2017). Morris and Liguori (2016) believe that invention and students exceeding their own expectations generally trigger the above-stated personality traits. In particular, the bootstrapping approach of student companies is effective to balance creative thinking and practicability (Crittenden et al., 2015). In addition, Pittaway et al. (2015) argue that involvement in student societies on entrepreneurship have proven to enhance students' confidence and intentions to become entrepreneurs. 
Table 1. Effects of Entrepreneurship Education on Different Levels of Society (compiled by the authors)

\begin{tabular}{|c|c|c|c|c|}
\hline . & Students & Companies & Society & Sources \\
\hline $\begin{array}{l}\text { Economic } \\
\text { growth }\end{array}$ & $\begin{array}{l}\text { Entrepreneurship } \\
\text { is vital for } \\
\text { economic } \\
\text { growth }\end{array}$ & $\begin{array}{c}\text { Entrepreneurial } \\
\text { workers are } \\
\text { key in long- } \\
\text { term growth }\end{array}$ & $\begin{array}{l}\text { Innovation is } \\
\text { important for } \\
\text { economic } \\
\text { progress }\end{array}$ & $\begin{array}{c}\text { (Jockenhöfer, } \\
\text { 2013; Pablos, } \\
\text { Lee, \& Zhao, } \\
\text { 2010; Zhang \& } \\
\text { Stough, 2013) }\end{array}$ \\
\hline Employment & $\begin{array}{l}\text { Entrepreneurs } \\
\text { are needed in } \\
\text { today's } \\
\text { globalised world }\end{array}$ & $\begin{array}{l}\text { Companies } \\
\text { need workers } \\
\text { to support } \\
\text { business } \\
\text { growth }\end{array}$ & $\begin{array}{c}\text { Economic } \\
\text { growth creates } \\
\text { more } \\
\text { employment } \\
\text { opportunities }\end{array}$ & $\begin{array}{c}\text { (Bentz, 2016; } \\
\text { Lussier, } \\
\text { Corman, \& } \\
\text { Kimball, 2014; } \\
\text { Seifert, Leleux } \\
\text { \& Tucci, 2008) }\end{array}$ \\
\hline Globalisation & $\begin{array}{l}\text { Entrepreneurial } \\
\text { mind-set is } \\
\text { required to cope } \\
\text { with fast-paced } \\
\text { environment }\end{array}$ & $\begin{array}{c}\text { Companies' } \\
\text { global strategy } \\
\text { creates new } \\
\text { market } \\
\text { structures }\end{array}$ & $\begin{array}{c}\text { Open markets } \\
\text { need } \\
\text { entrepreneurial } \\
\text { people to } \\
\text { function at } \\
\text { every level }\end{array}$ & $\begin{array}{c}\text { (John \& Ferris, } \\
\text { 2017; Khanser, } \\
\text { 2007) }\end{array}$ \\
\hline $\begin{array}{c}\text { Skills / } \\
\text { Motivation }\end{array}$ & $\begin{array}{l}\text { Autonomy and } \\
\text { creativity results } \\
\text { in motivation } \\
\text { and joy }\end{array}$ & $\begin{array}{c}\text { Workers' } \\
\text { motivation is } \\
\text { key for success } \\
\text { of company }\end{array}$ & $\begin{array}{l}\text { Economic } \\
\text { growth is a } \\
\text { result of } \\
\text { business } \\
\text { growth }\end{array}$ & $\begin{array}{c}\text { (Ahlstrom \& } \\
\text { Bruton, 2009; } \\
\text { Brunsell \& } \\
\text { Fleming, 2014; } \\
\text { Oncioiu, 2013) }\end{array}$ \\
\hline $\begin{array}{c}\text { Social } \\
\text { challenges }\end{array}$ & $\begin{array}{l}\text { Students can } \\
\text { contribute to } \\
\text { society and } \\
\text { make profits }\end{array}$ & $\begin{array}{l}\text { Companies } \\
\text { shift focus } \\
\text { from profit- } \\
\text { oriented to } \\
\text { purpose- } \\
\text { oriented }\end{array}$ & $\begin{array}{c}\text { Social } \\
\text { challenges are } \\
\text { emphasised } \\
\text { instead of } \\
\text { economic } \\
\text { challenges }\end{array}$ & $\begin{array}{c}\text { (Ahmed, 2017; } \\
\text { Fukukawa, } \\
\text { 2014; Ziegler, } \\
\text { 2011) }\end{array}$ \\
\hline
\end{tabular}

Table 1 summarises the impact of entrepreneurship education on different levels of society. This table also shows how the concept of entrepreneurship has evolved over the years in the United Kingdom and the Netherlands, but also shows the effects entrepreneurial education has on different levels of society. This review highlights the many challenges in entrepreneurship education, including the definitional confusion, the range of different entrepreneurial programs and the lack of guidance for universities to implement effective initiatives. Yet, with the given autonomy by governments, universities should fill the gap by streamlining entrepreneurship education with partner universities to the extent that it can enhance universities' entrepreneurial environments. The late developments in social entrepreneurship has resulted in booming scholars' interest in solving societal challenges and contribute to a good cause (Dyck \& Neubert, 2008; Lyons, 2013). Aaltio and Eskelinen (2016) suggest that the effects of social entrepreneurship are especially visible in areas that were previously not interesting for for-profit entrepreneurs. However, there is still not a clear view on how to teach entrepreneurship while there is no consensus on how universities should be structuring their entrepreneurial environment for best results (Yang, 2016). 
Therefore this research will further examine these aspects by exploring the related processes in two universities and thus gain an in-depth understanding on how universities can further improve their entrepreneurial practices to the benefit of students.

\section{Methodology}

In this study, the inductive approach is evident through the collection of qualitative data, a flexible approach and direct involvement from the researcher in the research process (Rose, Spinks, \& Canhoto, 2014). The authors have used Given's (2008) and Swanson and Holton's (2005) suggestion that the approach is best used for small samples of qualitative data as it takes into consideration the context where research effort is focused. We have gathered qualitative data by means of in-person semi-structured interviews, and therefore considered the inductive approach the most appropriate.

The authors considered the use of a case study the most appropriate strategy, as it allowed for identifying similarities and differences among the entrepreneurial offerings and academic perspectives at both universities. With the use of a case study an in-depth understanding of the role of the universities in entrepreneurship was achieved, as the study focused on 'how' and 'why' questions (Yin, 2013). The interview agenda and the questions that we asked can be found n Appendix A. In addition, several other scholars have used case study research in the past to perform an investigation on entrepreneurship education at universities (Ghina, 2014; Kilasi, 2014; Zande, 2012).

The research method selected for this paper is the qualitative approach, because it focuses on conceptualisation, as opposed to the quantitative approach that emphasises diagrams and statistics (Saunders, Lewis, and Thornhill, 2009). As this research into entrepreneurship education at partner universities is exploratory, the authors have selected a qualitative technique in order to gather 'rich' data with small samples (Gratton \& Jones, 2010). The qualitative approach was evident in this research as it concerned participants' personal views on and experiences with entrepreneurship education.

The interviewees were selected because of their entrepreneurial background and relevant roles in the two universities. We interviewed academics that are Entrepreneurship lecturers, relevant programme leaders as well as entrepreneurship managers helping and supporting students in their entrepreneurial career development.

The interviews ranged from 45 to 60 minutes in duration. Four interviews were conducted with University B, and three interviews were conducted with University A (please see table 2). All interviews were audio recorded through the use of a recording application on a smartphone. This, in turn, allowed the authors to give participants full attention during the interviews and obtain a record of the entire interview that was used for transcribing. The participants of the semistructured interviews were chosen using a non-probability sampling technique, aimed at selecting the interviewees that are most able to deliver relevant and 
reliable information (Saunders, Lewis, \& Thornhill, 2009). Participants A, B, D, E and $\mathrm{F}$ were asked to participate based on their lecturer's perspective, whereas participants $\mathrm{C}$ and $\mathrm{G}$ were selected based on their coordinator's perspective. This allowed for rich data collection as perspectives were from different faculties and functions in the universities.

Table 2. Identification of Research Participants

\begin{tabular}{|l|c|c|c|}
\hline \multicolumn{2}{|c|}{ University A } & \multicolumn{2}{c|}{ University B } \\
\hline Participant A & Programme Director & Participant D & Lecturer Entrepreneurship \\
\hline Participant B & $\begin{array}{c}\text { Lecturer Entrepreneurial } \\
\text { Business Management }\end{array}$ & Participant E & Lecturer Entrepreneurship \\
\hline \multirow{2}{*}{ Participant C } & $\begin{array}{c}\text { Student Enterprise } \\
\text { Manager }\end{array}$ & Participant F & $\begin{array}{c}\text { Lecturer International } \\
\text { Entrepreneurship }\end{array}$ \\
\cline { 2 - 4 } & Participant G & $\begin{array}{c}\text { Entrepreneurship } \\
\text { Education Manager }\end{array}$ \\
\hline
\end{tabular}

As suggested by Aurini, Heath, and Howells (2016), coding is the main way to bring order to qualitative data as it helps retrieving and organising the data, and it speeds up the analysis. More specifically, template analysis has been used to code the transcribed interviews with particular themes. This involved identifying the key themes from each interview and comparing the answers of the participants. In addition, by using template analysis the authors were able to define relationships between themes in entrepreneurship education, which allowed a deeper, more comprehensive analysis (King \& Brooks, 2016). The authors are not claiming that the findings of this research are generalizable. This is in line with Saunders, Lewis, and Thornhill (2009), who wrote that a study should focus on the situation, as long as there is no claim that the results, conclusions or theory can be generalised.

\section{Findings and Discussion}

The data gathered was thoroughly reviewed and coded using the template analysis approach to identify key themes. According to King (2002: 256), "the method refers to a varied but related group of techniques for thematically organising and analysing textual data". The method allowed the researchers to use a flexible approach that could be altered to the study and to analyse the perspectives of different people within the university context. Three main themes were identified through the analysis: the purpose and importance of entrepreneurship education, approaches to entrepreneurship education, cross case comparison of the entrepreneurial initiatives between institution $\mathrm{A}$ and $\mathrm{B}$. We discuss these themes in detail below. 


\section{The Purpose and Importance of Entrepreneurship Education}

The authors found that the participants of both universities consider the purpose of entrepreneurship education to open up students for other possibilities beyond 'being employed' and growing students' employability skills. This was also found by Sethna, Jones, and Harrigan (2013). Participant G was of the opinion that students should be ready to generate work for themselves, while participant $\mathrm{C}$ believed that the next generation is going to have a portfolio career, as opposed to one or two jobs, arguing, "one has to be prepared for the changing work environment by taking on enterprising skills" (Participant C). This clearly illustrates an understanding with both universities towards the importance and purpose of entrepreneurship education.

Also, each participant was asked about the best approach of teaching entrepreneurship. In the before-mentioned nature-nurture debate on an entrepreneurial mind-set, participants of both universities clearly position themselves on the nurture side. Participant B emphasised that students learn about entrepreneurship by doing it, whereas participant D argued that students that come in with a non-entrepreneurial attitude discover more about themselves and eventually $80 \%$ of this group concludes that they can come up with something new.

The importance of entrepreneurship education was not limited to the participants' perspectives. Instead, a widely accepted view on both universities' decision-making level was that the development of an entrepreneurial mind-set is crucial. This is important, as emphasised by Welsh (2014), who argued that board members often contribute to student learning with their mentoring and networking activities with students. However, participants at University A pointed out that the institution does not recognise entrepreneurship education as a top priority. Participant B underlined that entrepreneurial programs generally lack the financial and human resources to promote enterprise and start-up across University A. In addition, participant $\mathrm{C}$ noted, "I think we are a little bit slow to adopt that approach of entrepreneurship education over the whole institution".

In contrast, at University B, "the focus is on getting students ready for business life", but, "there is too less emphasis on the career perspective of selfemployed" (Participant G). The arguments of participants of both universities indicate that the institutional bodies do not fully recognise the importance of entrepreneurship education. This is worrisome, as suggested by Hosu and Iancu (2016), who argued that the role of higher education institutions is the most critical as universities are influencing scholars to form start-ups and thus directly contributing to the economic development of a country.

"Enterprise education is not just thinking about those individuals who are planning on setting up a business, it is about creating an enterprising mindset, which may lead to go down the road to set up a new business, but it will lead many to an organisation and being an intrapreneur" (Participant C). 
Participants D, F and G embraced the terminology of 'entrepreneurship education' and considered it as a combination of theory and practice. Participant D defined the term in two layers. First, it has to facilitate students with an entrepreneurial attitude that they want to start up their own company. Second, it is about cooperation skills.

The literature suggests that a distinction between enterprise and entrepreneurship education is desired. This is evident at University A, as opposed to University B, and is supported by Kompf (2012), who argued that enterprise and entrepreneurship education should be separated, with the former being delivered across the university and the latter being taught to individuals seeking to create a business.

Participants A and B explained that the core focus of the initiatives at University $\mathrm{A}$ is on someone setting up a business and the integration of the entrepreneurial mind-set. Participant $\mathrm{C}$ criticised, "universities tend to focus to create links with large employers, rather than necessarily the small and mediumsized sector". The literature already suggested that collaboration with SMEs is favourable for universities in terms of flexibility, the possibility for government funding and the opportunity to get into niche sectors such as technology and innovation (Fayolle and Redford, 2014). Participant A furthermore noted that a "social enterprise approach" has been acknowledged, but, "it is still an area that is not given due attention".

Table 3. Summary of the Purpose and Importance of Entrepreneurship Education

\begin{tabular}{|c|c|c|}
\hline $\begin{array}{c}\text { Importance of } \\
\text { entrepreneurship } \\
\text { education }\end{array}$ & $\begin{array}{c}\text { Enterprising skills required to } \\
\text { be prepared for changing work } \\
\text { environment }\end{array}$ & $\begin{array}{c}\text { Students should be ready to } \\
\text { generate work for themselves }\end{array}$ \\
\hline $\begin{array}{c}\text { Best approach of } \\
\text { entrepreneurship } \\
\text { education }\end{array}$ & Learn by doing & $\begin{array}{c}\text { Show students that the } \\
\text { unimaginable can be done }\end{array}$ \\
\hline $\begin{array}{c}\text { Attitude of decision- } \\
\text { makers }\end{array}$ & $\begin{array}{c}\text { Entrepreneurship not } \\
\text { recognised as top priority, thus } \\
\text { slow to adapt initiatives and } \\
\text { lack financial and human } \\
\text { resources }\end{array}$ & $\begin{array}{c}\text { Too less emphasis on career } \\
\text { perspective of self-employed, as } \\
\text { the focus is on getting students } \\
\text { ready for business life }\end{array}$ \\
\hline $\begin{array}{c}\text { Terminology } \\
\text { Types of } \\
\text { Entrepreneurship }\end{array}$ & $\begin{array}{c}\text { Focus on start-ups and large } \\
\text { companies }\end{array}$ & Focus on start-ups and SMEs \\
\hline
\end{tabular}

Participants D, E and G stressed that programs at University B are focused on business start-ups and the adaptation of the entrepreneurial mind-set and attitude. As opposed to University A, close collaboration with SMEs was evident in University B. 'Large Companies', however, are not involved in the program. Participant D elaborated, "we have not taken that step yet, where companies have an active voice in our curriculum". The importance of large companies is however 
significant in order to ensure a sustainable entrepreneur-ship ecosystem (Isenberg, 2013). Despite the increasing importance of social entrepreneurship, the participants at University B did not mention this concept, which suggests that there is no initiative in place that covers this area. The main findings in this theme are summarised in table 3 .

\section{Approaches to Entrepreneurship Education}

Although the participants at both universities acknowledged that entrepreneurial engagement from people and companies are needed in order to survive in the demanding environment we nowadays live in, they have highlighted different approaches the universities take to expose students to this environment.

In terms of scope, University A has not embedded an international approach to entrepreneurship offerings. In fact, participants B and C suggested that it is not part of any program to gain experience in the business environment during studies. Participant A acknowledged that students should be given the opportunity to acquire the skills by going out and work in enterprises, but noted, "probably the mass way of doing it would be to embed it in experiential learning, so that you give people the opportunity whilst they are on a program to practice those skills". In addition, participant $\mathrm{C}$ pointed out, "I want students to be able to be resilient, to think creatively, to work in difficult, challenging environments", but also criticised, "we only run extra-curricular activities, such as start-up weekends". This approach contradicts the secondary research, suggesting that a global consideration and experiential learning through internships and field experience is believed to be the best approach in equipping students with an entrepreneurial mind-set (Chan, Sipes, \& Lee, 2017; Greene et al., 2015).

When the same question was asked to participants at University B, the authors identified that a global approach was evident in the "International Entrepreneurship" modules and minors, as stressed by participants D, E and F. Participant D explained, "students are at the heart of a selfish process, which is called entrepreneurship education. But in doing so, they have to be aware of the business environment, where you focus on different people and markets". Participant F pointed out, "compared to other universities in The Netherlands, we are the only ones with an international approach". In this context, the university has a global approach through integrating mandatory work placements, exchange programmes and graduation assignments to be completed abroad. This illustrates that the suggested approach for entrepreneurship education is evident in University B.

Besides the general approach of entrepreneurship programs, the participants were also asked on the specific approach to trigger students' interest, joy and creativity. University A is stimulating students' traits through student societies on entrepreneurship and enterprises (Participant B). Involvement in student societies on entrepreneurship have proven to result in increased confidence and student intentions to become entrepreneurs (Pittaway et al., 2015). As opposed to taking opportunities outside the curriculum, participants B and C argued that students are best triggered with the bootstrapping of a business idea, that is, starting up your 
own business for the bare minimum in terms of resources that you need to get started. The bootstrapping approach to balance creative thinking and practicability was also suggested as an effective practice-based approach by Crittenden et al. (2015). This is also in line with Morris and Liguori (2016), who argued that these personality traits are best triggered by invention and exceeding their own expectations,

According to participants $\mathrm{D}, \mathrm{E}$ and $\mathrm{F}$, personal development is the key learning goal for students at University B, stimulating one to take initiative, think creatively and enjoy the process of setting up a business. Participants D, E and F emphasised the importance of freedom given to students to stimulate their entrepreneurial mind-set and generate new ideas. The authors noted that Gelderen and Masurel (2012) suggested that entrepreneurship education without a strong emphasis on autonomy is a waste for both students and society. The appreciation of freedom is often reflected in student feedback, frequently ranking entrepreneurship first in "most likeable course", and "some even emphasised that this course made them stay at the university" (Participant E). This is in line with the study carried out by Reffstrup and Christiansen (2017), who found that entrepreneurship education has increased students' motivation and decreased student boredom and dropout rates.

"We let students take a test on how entrepreneurial they are, because the question is often answered 'not really, not for me'. As they progress, you can see that they are actively involved." (Participant D)

Table 4 summarises the main findings of this theme.

Table 4. Summary of Main Approaches to Entrepreneurship Education between the Two Institutions

\begin{tabular}{|l|c|c|}
\hline & University A & University B \\
\hline Global approach & No & Yes \\
\hline $\begin{array}{l}\text { Expose students to } \\
\text { business environment }\end{array}$ & $\begin{array}{c}\text { Through extra-curricular } \\
\text { activities }\end{array}$ & $\begin{array}{c}\text { Mandatory part of } \\
\text { curriculum }\end{array}$ \\
\hline $\begin{array}{l}\text { Approach to stimulating } \\
\text { students }\end{array}$ & $\begin{array}{c}\text { Bootstrapping of business } \\
\text { idea and involvement of } \\
\text { student societies }\end{array}$ & $\begin{array}{c}\text { Let students take a test on } \\
\text { how entrepreneurial they are }\end{array}$ \\
\hline Long-term / short-term & Long-term approach & Short-term approach \\
\hline
\end{tabular}

\section{Cross Case Comparison of the Entrepreneurial Initiatives between Institution A and B}

At University B start-up entrepreneurship is embedded in different levels of the institution. Participants D, E and F are involved in short-term orientated modules and minors where students generate, test, and pitch an idea for a new product or service. However, as argued by participant D, "students are very careful with ideas implementation, because of the curriculum that requires work placements and minors abroad". Participant G noted, "it discourages students having to liquidate their company after such short period of time". This is also 
criticised by Manimala and Thomas (2017), who suggested that entrepreneurial education should always have a long-term focus instead of short term to allow student engagement and success of the program. Participant $\mathrm{E}$ further described the business unit at University B as an incubator where students with a markettested and feasible idea will get a coach and accessibility to financial and location resources. Nevertheless, participant $\mathrm{G}$ argued, "a lot do not do it, because they want to focus on study instead of setting up a company", and participant E confirmed, "very few students have attempted to set up a business". Despite the available programs for students that have a business or business idea, participant $G$ pointed out that there is no space for entrepreneurship in every domain within the university. The lack of integration across the university indicates that the gap between European and North American countries in terms of entrepreneurship education is not yet to be filled.

The authors remarked however that participants $\mathrm{B}$ and $\mathrm{C}$ mentioned "employability" as the main program goal of entrepreneurship education. On the other hand, the aim of Dutch institutions is to increase the number of scholars adapting an entrepreneurial mind-set and launching their own venture within five years after completing their studies. Although, as suggested before by participant $\mathrm{D}$, basically $80 \%$ of students are believed to have achieved the entrepreneurial mind-set, it is hard to measure and specific data is not available (Participant G).

As mentioned before, both universities are to a certain extent dependable on national frameworks imposed by the government and institution decision-making on entrepreneurial education, with the latter offering more flexibility. Fetters, Greene, and Rice (2010) argued that universities are triggered to support entrepreneurial courses to improve their competitive advantage, strengthen their alumni networks and improve their status and reputation. However, this research has shown that participants at both universities are not completely satisfied with the university initiatives and have suggested improvements to develop the entrepreneurial programs. This is important, as academics play a key role in carrying out the university's entrepreneurial spirit (Fetters, Greene, \& Rice, 2010).

Participant A emphasised the importance of social entrepreneurship, particularly because the university is trying to be relevant to the communities in which it serves locally, nationally and globally. This is relevant, considering the increasing importance of social entrepreneurs. Additionally, participants A, B and $\mathrm{C}$ believed that all students should be exposed to experiential-based learning, especially because in business the resources are relatively cheap, as opposed to engineering for example. Participant B suggested, "the university should aim for a much more integrated approach of entrepreneurship that would achieve the same thing without having it separated out, and that it is perceived as an employment option rather than only starting up an own business". Also, participants B and C criticised the lack of cohesion of enterprise and entrepreneurship activities within the university, which is believed to be a result of the promotion of the researchfocused agenda. 
"We are slow to adapt that approach of entrepreneurship education over the whole institutions, which is such a broad area that is fits everywhere." (Participant C)

Participants B and C would rather create a dedicated space, which should be home for student start-ups and enterprise societies, and which hosts specialist programs, alumni networking events, guest speaker programs and competitions. Furthermore, participant $C$ would like to see more collaboration with SMEs, especially in the field of digital tech, as the process of integrating in these companies is faster than in larger companies. Entrepreneurship centres provide support for the local ecosystem as well as benefitting from the programming and resources offered by off-campus entities (Kuratko \& Hoskinson, 2017). It is considered the most common means by which universities provide a range of programs and services that improve entrepreneurship and economic development. Entrepreneurship courses are most effective if they were linked to a 'centre' that offers access to academics, support services and collaboration with local entrepreneurs (Morris, Kuratko, \& Cornwall, 2013).

Similar to University A, participants D and E would like to see entrepreneurship embedded in a learning line across University B to expose all students to the mind-set connected with the concept. Participant D furthermore argued that a closer cooperation is required with business units within the university, and companies and universities on a local and global scale to widen students' entrepreneurial awareness. Besides the wider reach of entrepreneurship education, University B should also strive for the integration of technical studies with entrepreneurship, according to participant G. "I would like to see an environment where students can present their ideas and have the tools available to discover market demand and make prototypes" (Participant G). This environment would serve as a workspace for students of different faculties to work on an idea, and to meet with companies to further develop their idea. The need for entrepreneurship education embedded in engineering studies has been addressed widely to develop an entrepreneurial mind-set among students and combining that with engineering thinking and skills (Aaltio \& Eskelinen, 2016).

Where University A aims to be the heart of the Northeast, nationally and internationally, in the field of entrepreneurship education, University B does not have the ambition to become an incubator (Participant D, Participant G). The findings and discussion section has provided a comprehensive exploration of the data using template analysis, it integrated the findings with the literature hence offering a structured overview of the different initiatives and views of the universities on entrepreneurship education.

\section{Conclusions}

This study has investigated the differences in entrepreneurship education between two partner universities: University A and University B. 
It can be identified in the literature and the findings that entrepreneurship education is a multifaceted concept and that it is generally perceived as a method for teaching accumulated entrepreneurial activity. The case study universities have acknowledged that the purpose of entrepreneurship education is in accordance with established literature; to improve students' employability skills. The results of the research have proven that the concept of entrepreneur-ship education is considered highly important and should be exposed to all students in university.

The literature review and findings add substantial knowledge of how entrepreneurship education is differently perceived and implemented at two partner universities. Sá and Kretz's (2015) statement that universities are motivated to support entrepreneurial courses to improve their competitive advantage, strengthen their alumni networks and improve reputation is evident in both universities. Moreover, the research performed by Lackéus (2015) suggested that educational institutions are often left with the question "learning-by-doingwhat?" It can be concluded that this is evident within both universities, as there is no aligned view on what entrepreneurship education entails, how it should be educated, what students should take away from the program, and which new initiatives are desired by academics.

Analysis of the current entrepreneurial offerings at both universities identified that there is a different approach on triggering students' entrepreneur-rial mind-set and encourage start-ups and this was shown in the research findings. This was partly due to the institution's strategy, ambitions and scope. It can be concluded from the findings that University A has a more international and practical approach and is in line with Fayolle and Redford's (2014) and West, Gatewood and Shaver's (2009) findings that we are living in a globalized, uncertain and complex environment. Furthermore, the findings show that University B emphasizes the importance of enterprise education, as opposed to entrepreneurship education alone, which better fits the terminology of entrepreneurial education as stated by Ahmad and Seymour (2016). The differences between the universities are provided in table 5 .

Significant differences have been found between the universities in terms of terminology and types of entrepreneurship. As opposed to University B, University A used a distinction between entrepreneurship and enterprise education, indicating the importance of both developing an entrepreneurial mindset and stimulating start-ups. Furthermore, the study has shown that both universities lack the integration of certain types of organisations, suggesting that the priority is not on entrepreneurship education.

From the findings it is also evident that the scope and approach on entrepreneurship education is not in line with the literature. Nevertheless, the extent to which it impacts students may be influenced by variables including culture, role models and individual characteristics. It can be concluded that University B wants students to gain entrepreneurial experience through experience-based learning in an international environment in the context of mandatory internships and exchange programs. This is not apparent at University A, where experiential-based learning in the business environment is not a mandatory part in the entrepreneurial curriculums. 
Table 5. Differences between the two Universities

\begin{tabular}{|c|c|c|}
\hline & $\begin{array}{c}\text { University A } \\
\end{array}$ & $\begin{array}{c}\text { University B } \\
\end{array}$ \\
\hline $\begin{array}{l}\text { Start-up } \\
\text { environment }\end{array}$ & $\begin{array}{l}\text { Full-time curriculum on student } \\
\text { companies. Also incubation } \\
\text { facilities for offering mentoring } \\
\text { and specialist advise }\end{array}$ & $\begin{array}{l}\text { Modules and minors on } \\
\text { entrepreneurship with idea } \\
\text { generation and student companies. } \\
\text { Also incubation facilities }\end{array}$ \\
\hline Integration & $\begin{array}{l}\text { Separate curriculum. Incubator for } \\
\text { all current students and recent } \\
\text { graduates up to five years. }\end{array}$ & $\begin{array}{l}\text { Modules and minors not integrated } \\
\text { across all curriculums. Incubation } \\
\text { facilities for all current students. }\end{array}$ \\
\hline $\begin{array}{l}\text { Program } \\
\text { goal }\end{array}$ & Employability of students & $\begin{array}{l}\text { Increasing number of students with } \\
\text { entrepreneurial mind-set and } \\
\text { launching company within five } \\
\text { years of graduation }\end{array}$ \\
\hline $\begin{array}{l}\text { Desired } \\
\text { initiatives }\end{array}$ & $\begin{array}{l}\text { Focus on social entrepreneurship } \\
\text { and collaboration with SMEs. } \\
\text { Expose all students to } \\
\text { entrepreneurship, without } \\
\text { separating it in a module. Create } \\
\text { entrepreneurship centre. }\end{array}$ & $\begin{array}{l}\text { Introduce entrepreneurship learning- } \\
\text { line across university. Closer } \\
\text { cooperation with business units } \\
\text { within university, and companies } \\
\text { and universities globally. Integration } \\
\text { with engineering studies. }\end{array}$ \\
\hline Ambitions & $\begin{array}{l}\text { Leader in entrepreneurship } \\
\text { education of Northeast }\end{array}$ & $\begin{array}{l}\text { Not the ambition to become an } \\
\text { incubator }\end{array}$ \\
\hline
\end{tabular}

Our research has shown that participants at both universities believed entrepreneurship education is about enhancing student's personality traits, such as creativity, resilience and dedication. This is believed to match entrepreneurial students' personality traits as high risk-takers and control-seekers, as suggested by the literature.

From the literature it was found that there is a wide diversity of initiatives to support entrepreneurship education in universities. This is evident at University A, where outperforming other universities by means of offering the most appealing environment is an important goal. University B, on the other hand, has a more reserved role in entrepreneurship education despite the autonomy given by the Dutch government. It can be concluded from the research that the entrepreneurship initiatives implemented at University A focuses more on employability skills of students, whereas University B aims primarily at increasing the number of scholars adapting the entrepreneurial mind-set.

Furthermore, University A recognised to a greater extent that scholars are inspired to have a positive impact on economic development. Hence, the start-up environment and ambitions of University A are more explicit than the initiatives and desires at University B. The research furthermore concluded that University A wanted to follow the trend of entrepreneurship education shifting to encounter societal challenges, as opposed to University B.

Future research can add more participants in the primary research which would have strengthened the data, allowing more views and experiences on entrepreneurship education at both universities. An extended research period in combination with the availability and efforts of participants, academics could have been requested from a wider range of faculties within both universities, allowing improved data collection. Furthermore, an increased number of participants could 
have resulted in the collection of quantitative data, too. Lastly, a thorough analysis of the external environment, including the influence of the government other stakeholders, would provide more insights in the 'why' behind certain initiatives.

\section{References}

Aaltio, I., \& Eskelinen, M.T. (2016). Proceedings of The $11^{\text {th }}$ European Conference on Innovation and Entrepreneurship. Proceedings of The 11th European Conference on Innovation and Entrepreneurship. Jyvaskyla: The JAMK University of Applied Science.

Acs, Z., Szerb, L., \& Autio, E. (2017). Global Entrepreneurship and Development Index 2016. Springer.

Ahlstrom, D., \& Bruton, G.D. (2009). International Management: Strategy and Culture in the Emerging World. Cengage Learning.

Ahmad, N., \& Seymour, R.G. (2016). Defining Entrepreneurial Activity: Definitions Supporting Frameworks for Data Collection. OECD.

Ahmed, A. (2017). Managing Knowledge and Innovation for Business Sustainability in Africa. Springer.

Ahmetoglu, G. (2017). The Wiley Handbook of Entrepreneurship. John Wiley and Sons.

Aurini, J.D., Heath, M., \& Howells, S. (2016). The How To of Qualitative Research: Strategies for Executing High Quality Projects. SAGE.

Baptista, R., \& Leitão, J. (2015). Entrepreneurship, Human Capital, and Regional Development: Labor Networks, Knowledge Flows, and Industry Growth. Springer.

Bentz, H. (2016). Rationing Earth: Economic Strategy by Design. FriesenPress.

Bijaoui, I. (2015). The Open Incubator Model: Entrepreneurship, Open Innovation, and Economic Development in the Periphery. Springer.

Brunsell, E., \& Fleming, M.A. (2014). Engaging Minds in Science and Math Classrooms: The Surprising Power of Joy. ASCD.

Chan, C., Sipes, B.S., \& Lee, T. (2017). Enabling Agri-entrepreneurship and Innovation: Empirical Evidence and Solutions for Conflict Regions and Transitioning Economies. CABI.

Crittenden, V.L., Esper, K., Karst, N., \& Slegers, R. (2015). Evolving Entrepreneurial Education: Innovation in the Babson Classroom. Emerald Group Publishing.

Dyck, B., \& Neubert, M. (2008). Management: Current practices and new directions. Cengage Learning.

EACEA. (2012). Entrepreneurship Education at School in Europe. Brussels: EACEA.

EACEA. (2016). Entrepreneurship Education at School in Europe. EACEA.

Ehiobuche, C., \& Madueke, C. (2017). Youth Entrepreneurship: From Job Search to Business Ownership and Self-Sufficiency. Xlibris Corporation.

Fayolle, A., \& Redford, D.T. (2014). Handbook on the Entrepreneurial University. Edward Elgar Publishing.

Fetters, M., Greene, P.G., \& Rice, M.P. (2010). The Development of University-based Entrepreneurship Ecosystems: Global Practices. Edward Elgar Publishing.

Fukukawa, K. (2014). Corporate Social Responsibility and Local Community in Asia. Routledge.

Gelderen, M.V., \& Masurel, E. (2012). Entrepreneurship in Context. Routledge.

Ghina, A. (2014). Effectiveness of Entrepreneurship Education in Higher Education Institutions. Procedia - Social and Behavioral Sciences, 115, 332-345. 
Given, L.M. (2008). The Sage Encyclopedia of Qualitative Research Methods: A-L,vol. 2. SAGE.

Gratton, C., \& Jones, I. (2010). Research Methods for Sports Studies. Taylor and Francis.

Greene, P.G., Brush, C.G., Eisenman, E.J., Neck, H., \& Perkins, S. (2015). Entrepreneurship education: A global consideration from practice to policy around the world. Retrieved from https://bit.ly/2DcZBEY.

Hosu, I., \& Iancu, I. (2016). Digital Entrepreneurship and Global Innovation. IGI Global.

Hytti, U., Blackburn, R., Fletcher, D., \& Welter, F. (2016). Entrepreneurship, Universities and Resources: Frontiers in European Entrepreneurship Research. Edward Elgar Publishing.

Information Resources Management Association. (2017). Entrepreneurship: Concepts, Methodologies, Tools, and Applications: Concepts, Methodologies, Tools, and Application. IGI Global.

Isenberg, D. (2013). Worthless, Impossible and Stupid: How Contrarian Entrepreneurs Create and Capture Extraordinary Value. Cambridge, MA: Harvard Business Review Press.

Jockenhöfer, M. (2013). How to promote entrepreneurship within established companies? Human Resource Management and Corporate Entrepreneurship. Anchor Academic Publishing.

John, K., \& Ferris, S.P. (2017). Global Corporate Governance. Emerald Group Publishing.

Jones, O., Macpherson, A., \& Jayawarna, D. (2013). Resourcing the Start-Up Business: Creating Dynamic Entrepreneurial Learning Capabilities. Routledge.

Karlsson, C., Grasjo, U., \& Wixe, S. (2015). Innovation and Entrepreneurship in the Global Economy. New Horizons in Regional Science.

Khanser, M.A. (2007). John L. Gokongwei, Jr: the path of entrepreneurship. Loyola Schools, Ateneo de Manila University.

Kilasi, P.K. (2014). The role of higher education in promoting entrepreneurship education : the case of public universities in Tanzania. University of Pretoria.

King, N. (2002). Using Templates in the Thematic Analysis of Text.

King, N., \& Brooks, J.M. (2016). Template Analysis for Business and Management Students. SAGE.

Kompf, M. (2012). Entreplexity ${ }^{\circledR}=$ Entrepreneurship + Complexity: The Writing and Thoughts of Gene Liczkiw. Springer Science and Business Media.

Kuratko, D.F., \& Hoskinson, S. (2017). The Great Debates in Entrepreneurship. Emerald Group Publishing.

Lackéus, M. (2015). Entrepreneurship in Education. Paris: OECD.

Lussier, R. N., Corman, J., \& Kimball, D. (2014). Entrepreneurial New Venture Skills. Routledge.

Lyons, T.S. (2013). Social Entrepreneurship: How Businesses Can Transform Society, vol. 1. ABC-CLIO.

Manimala, M.J., \& Thomas, P. (2017). Entrepreneurship Education: Experiments with Curriculum, Pedagogy and Target Groups. Springer.

Miri, Y. (2014). Entrepreneurship in the education system - the revolution of the twentyfirst century. Journal of Enterprising Communities: People and Places in the Global Economy, 8(1), https://doi.org/10.1108/JEC-11-2013-0035.

Mitra, J., \& Edmondson, J. (2015). Entrepreneurship and Knowledge Exchange. Routledge.

Morris, M.H., \& Liguori, E. (2016). Annals of Entrepreneurship Education and Pedagogy. Edward Elgar Publishing. 
Morris, M.H., Kuratko, D.F., \& Cornwall, J.R. (2013). Entrepreneurship Programs and the Modern University. Edward Elgar Publishing.

Moroz, P.W., \& Hindle, K. (2012). Entrepreneurship as a process: Toward harmonizing multiple perspectives. Entrepreneurship Theory and Practice, 36(4), 781-818.

Myers, M. (2014). UK rises to fourth most entrepreneurial economy in the world. Imperial College London.

Nicolescu, O., \& Lloyd-Reason, L. (2016). Challenges, Performances and Tendencies in Organisation Management. World Scientific.

OECD. (2009). Universities, innovation and entrepreneurship, OECD.

Oncioiu, I. (2013), Business Innovation, Development, and Advancement in the Digital Economy. IGI Global.

Pablos, P. O., Lee, W. B., \& Zhao, J. (2010). Regional Innovation Systems and Sustainable Development: Emerging Technologies: Emerging Technologies. IGI Global.

Pantea, M.-C., Diroescu, R., \& Podlasek-Ziegler, M. (2014). Young people, entrepreneurship and non-formal learning: A work in progress. SALTO-Youth Participation.

Papadopoulos, P.M., Burger, R., \& Faria, A. (2016). Innovation and Entrepreneurship in Education. Emerald Group Publishing.

Passiante, G., \& Romano, A. (2016). Creating Technology-Driven Entrepreneurship: Foundations, Processes and Environments. Springer.

Pittaway, L.A., Gazzard, J., Shore, A., \& Williamson, T. (2015). Student clubs: experiences in entrepreneurial learning, Entrepreneurship and Regional Development, 27(3-4), 127-153.

Rae, D., \& Wang, C.L. (2015). Entrepreneurial Learning: New Perspectives in Research, Education and Practice. Routledge.

Rae, D., \& Woodier-Harris, N. (2013). International Entrepreneurship Education: postgraduate business students experiences of Entrepreneurship Education. University of Lincoln.

Rahman, S.A. (2016). Developments in Higher Education: National Strategies and Global Perspectives (Penerbit USM). Penerbit USM.

Raposo, M., \& Paço, A.D. (2011). "Entrepreneurship education: Relationship between education and entrepreneurial activity." Psicothema, 23(3), 453-457.

Reffstrup, T., \& Christiansen, S.K. (2017). Nordic Entrepreneurship Islands: Status and potential Mapping and forecasting Entrepreneurship Education on seven selected Nordic Islands. Nordic Council of Ministers.

Riviezzo, A., Nisco, A. D., \& Napolitano, M.R. (2012). Entrepreneurship Higher Education in Europe: State of the Art and Marketing Insights to Enhance the Attraction of Foreign Students. GRIN Verlag.

Rose, S., Spinks, N., \& Canhoto, A. I. (2014). Management Research: Applying the Principles. Routledge.

Sá, C., \& Kretz, A. (2015). The Entrepreneurship Movement and the University. Springer.

Saunders, M., Lewis, P., \& Thornhill, A. (2009). Research Methods for Business Students. Pearson Education.

Seifert, R.W., Leleux, B.F., \& Tucci, C.L. (2008). Nurturing Science-based Ventures: An International Case Perspective. Springer Science and Business Media.

Sethna, Z., Jones, R., \& Harrigan, P. (2013). Entrepreneurial Marketing: Global Perspectives, Emerald Group Publishing.

Shockley, G.E. (2009). Non-market Entrepreneurship: Interdisciplinary Approaches. Edward Elgar Publishing. 
Swanson, R.A., \& Holton, E.F. (2005). Research in Organizations: Foundations and Methods in Inquiry. Berrett-Koehler Publishers.

Telman, R. (2012). Entrepreneurial processes in a cultural context - the influence of uncertainty avoidance on entrepreneurial processes in Denmark. University of Twente.

UNESCO. (1998). Higher Education in the Twenty-first Century Vision and Action. Paris: UNESCO.

Urban, B., \& Kujinga, L. (2017). The Institutional Environment and Social Entrepreneurship Intentions. International Journal of Entrepreneurial Behaviour and Research, 23(4), 638-655.

Valerio, A., Parton, B., \& Robb, A. (2014). Entrepreneurship Education and Training Programs around the World: Dimensions for Success. World Bank Publications.

Welsh, D. (2014). Creative Cross-Disciplinary Entrepreneurship: A Practical Guide for a Campus-Wide Program. Springer.

West, G.P., Gatewood, E.J., \& Shaver, K.G. (2009). Handbook of University---wide Entrepreneurship Education. Edward Elgar Publishing.

Wright, M. (2007). Academic Entrepreneurship in Europe. Edward Elgar Publishing.

Yang, A. (2016). Why Entrepreneurship Education Does Not Work. Forbes .

Yin, R.K. (2013). Case Study Research: Design and Methods. SAGE Publications.

Zande, J.V. (2012). Fostering Entrepreneurship at Universities Utrecht University.

Zhang, T., \& Stough, R. (2013). Entrepreneurship and Economic Growth in China. World Scientific.

Zhou, M., \& Xu, H. (2012). A Review of Entrepreneurship Education for College Students in China. MDPI, 82-98.

Ziegler, R. (2011). An Introduction to Social Entrepreneurship. Edward Elgar Publishing. 


\section{Appendix A}

Interview Agenda

\begin{tabular}{|c|c|}
\hline Introductory questions & $\begin{array}{l}\text { How long have you been teaching entrepreneurship for? } \\
\text { What is the name of the entrepreneurship program? } \\
\text { Which entrepreneurial initiatives are you involved in? } \\
\text { What do you want your students to take away from the } \\
\text { program? }\end{array}$ \\
\hline $\begin{array}{l}\text { Entrepreneurship } \\
\text { Education }\end{array}$ & $\begin{array}{l}\text { How would you best describe entrepreneurship } \\
\text { education? } \\
\text { How do you believe entrepreneur ship should be taught? } \\
\text { What are the institutional factory driving the university's } \\
\text { participation in entrepreneurship education? } \\
\text { What external influences are driving the university's } \\
\text { participation in entrepreneurship education? } \\
\text { How does the university benefit from participating in } \\
\text { entrepreneurial education? }\end{array}$ \\
\hline University Offerings & $\begin{array}{l}\text { What are the different university offerings? } \\
\text { How do scholars know about the existence? } \\
\text { Would you make any changes to current initiatives? } \\
\text { How and to what extent does the university fund students } \\
\text { pursuing entrepreneurship? } \\
\text { How does the university's participation in } \\
\text { entrepreneurship education change the experience of } \\
\text { students? } \\
\text { How are students triggered to be engaged? }\end{array}$ \\
\hline
\end{tabular}

